\title{
Features of the structure of family relationships in organization of sports and recreational activities
}

\author{
Valery Ilyin ${ }^{1, *}$, Sergey Tarasov $^{1}$, Alexey Ilyin $^{1}$, Elena Tarasova $^{1}$, Olga Belova $^{1}$ \\ ${ }^{1}$ Penza State University, Penza, Russia
}

\begin{abstract}
The article looks into the issue of social adaptation and personal adjustment of people with disabilities through their active participation in regular classes of adaptive exercise therapy. Based on state statistics, scientific publications analysis and research work a hypothesis was put forward that there is an additional factor that plays a significant role in the family upbringing scheme and helps to foster interest in adaptive exercise therapy and adaptive sports among intellectually impaired children. The purpose of the study was to identify a factor or group of factors in the family upbringing scheme which are relevant to methodology of arranging PE and sports events for children with intellectual disabilities. The sample group consisted of women whose children, including those with intellectual disabilities, attended sports schools in Russia. Among the methods applied during the study there were psychodiagnostic methods of written and oral interviews, questionnaires. The results of the procedures of statistical and factor analysis revealed destructive aspects in the field of child-parent relationship as well as interpersonal relationship. The family dysfunctions correction will make it possible to apply integrative technologies in organizing sports and recreational events for families where children with intellectual disabilities are brought up.
\end{abstract}

\section{Introduction}

Nowadays the work is underway aiming to help children with intellectual disabilities to adapt and socialize using adaptive exercise therapy and adaptive sports, which are considered the most effective and contributing means of correcting developmental disorders among the children of this category regarding their better social adaptation and integration $[1,2,3,4,5$, 6 , 7]. According to the Federal State Statistics Service of Russia, as of April 2019, the total number of people with disabilities aged over 15 was $11,947,000$ ( 81.4 per 1000 people) in which connection it is worth mentioning that, according to the Comprehensive Monitoring of Living Conditions of the Population, $89.1 \%$ of respondents with disabilities are noted as incapable of leading a healthy life due to their health status or age, $4.7 \%$ have no interest or desire to lead a healthy life, $5.2 \%$ are engaged in adaptive exercise therapy, $4.6 \%$ attend sporting events as spectators.

\footnotetext{
* Corresponding author: ilyina_hz2@mail.ru
} 
According to the statistical data of the Main Directorate of Rehabilitation Service and Correctional Education of the Ministry of Education of the Russian Federation, at present time more than $60 \%$ out of more than 600 thousand secondary school students with disabilities are children with intellectual disabilities.

Numerous sociological studies have shown that a habit of doing sport and exercises should be formed in the person's childhood, and the people who bear main responsibility for the process are the parents, especially if they raise a child with intellectual disabilities $[8,9$, $10,11,12]$.

It is the family that appears to be the major and sometimes the only environment shaping the lifestyle of a child with intellectual disabilities. Any educational center, either a secondary school or an adaptive sports school, as well as the family are significant institutions for correction, adaptation and socialization of a child with intellectual disabilities, and their competent interaction determines the efficiency of the child's balanced development $[13,14$, 15].

Therefore, improvement of socio-educational complex for rehabilitation and social adaptation of children with intellectual disabilities by developing their cognitive and physiological functions through the system of family relationships in the process of involving them in adaptive exercise therapy and adaptive sports still remains of current importance.

With reference to the foregoing we hypothesized the existence of an additional factor or group of factors in the sphere of bringing up children attending sports classes, based on the purpose of the study which is to identify the presence of such factors that determine the methodology of organizing physical education and sports events for children with intellectual disabilities

The aim of the study was to identify the presence of a factor or group of factors in the sphere of family upbringing which could be relevant to methodology of conducting physical education and sports events for children with intellectual disabilities.

\section{Research results and discussion}

The study was conducted on the basis of Russian sport schools: Penza children and youth sports school (CYSS) number 3 and adaptive sports school (ASS) of Penza region. The sample consisted of mothers whose children studied in these sports schools. The study involved 86 women (44 people from DYSS group and 42 people from ASS group) aged from 21 to 48 . Methods of written survey and questionnaire were applied. The following techniques were used to collect empirical data: PARI technique by E. Schaeffer and R. Bell (adapted by T. V. Nescheret -"Family life through the eyes of a mother") designed to study mothers' attitude to their family role and to their child, and Sax Levy's "Unfinished Sentences" test ( SSCT ). To process the obtained material there were used methods of mathematical statistics to determine the arithmetic mean value (M), modes (Mo), Student's t-test, and AtteStat software.

\section{Results and discussion}

After the questionnaire data have been processed and presented in PARI spreadsheet some meaningful figures were found in the cells "Attitude to the family role" and "Parents' attitude to the child: excessive concentration on the child". Relying on characteritics of the cells and analysis of the diagnostic study results, we can notice in both groups some indicators of destructive features in the family relationships that provoke conflicts caused by personal aspirations of a certain woman, and are reduced by the scope of the family system roles and functions. 
Figure 1 in the cell "Attitude to the family role" shows summary data of primary statistics for the arithmetic mean (M) taking into account the extent of indicator's variability according to the standard deviation (S), the mean error $(\mathrm{m})$, and the calculation of Student's $\mathrm{t}$-test for reliability of differences $\left(\mathrm{t}_{\mathrm{cr}}=2.02\right.$ with $\mathrm{p} \leq 0.05 ; \mathrm{t}_{\mathrm{cr}}=2.69$ with $\left.\mathrm{p} \leq 0.01\right)$. The differences, as a result of comparing the figures for the two studied groups, can be considered reliable by two indicators: "Feeling of self-sacrifice in the role of a mother" $\left(t_{\mathrm{emp}}=3.1\right)$ and "Dissatisfaction with the role of the lady of the house" $\left(\mathrm{t}_{\mathrm{emp}}=3.3\right)$.

\begin{tabular}{|l|c|c|c|c|c|}
\hline \multirow{2}{*}{$\begin{array}{l}\text { Names of indicators in the cell } \\
\text { "Attitude to the family role" }\end{array}$} & \multicolumn{2}{|c|}{$\begin{array}{c}\text { ASS } \\
\mathrm{n}=44\end{array}$} & \multicolumn{2}{c|}{$\begin{array}{c}\text { DYSS } \\
\mathrm{n}=42\end{array}$} & $\begin{array}{c}\text { Reliabili } \\
\text { ty of } \\
\text { differenc } \\
\mathrm{es}_{\mathrm{em}}\end{array}$ \\
\cline { 2 - 6 } & $\mathrm{M}( \pm \mathrm{m})$ & $\mathrm{S}$ & $\mathrm{M}( \pm \mathrm{m})$ & $\mathrm{S}$ & 1 \\
\hline $\begin{array}{l}\text { Contracted interests of a } \\
\text { woman whi ch are reduced to } \\
\text { family care }\end{array}$ & $12.4 \pm 0.50$ & 2.43 & $13.3 \pm 0.70$ & 3.23 & 1 \\
\hline $\begin{array}{l}\text { Feeling of self-sacrifice in the } \\
\text { role of a mother }\end{array}$ & $15.5 \pm 0.34$ & 1,64 & $13.4 \pm 0.58$ & 2.72 & 3.1 \\
\hline Family conflicts & $13.4 \pm 0.69$ & 3.35 & $12.5 \pm 0.48$ & 2.24 & 1.1 \\
\hline Parents' authoritativeness & $14.6 \pm 0.42$ & 0.06 & $14.8 \pm 0.57$ & 2.67 & 0.3 \\
\hline $\begin{array}{l}\text { Dissatisfaction with the role of } \\
\text { the lady of the house }\end{array}$ & $13.7 \pm 0.40$ & 1.97 & $11.1 \pm 0.67$ & 3.15 & 3.3 \\
\hline $\begin{array}{l}\text { Husband 's indifference } \\
\text { and lack of involvement in } \\
\text { family affairs }\end{array}$ & $12.3 \pm 0.39$ & 1.90 & $12.5 \pm 0.57$ & 2.67 & 0.2 \\
\hline Mother's domination & $11.7 \pm 0.75$ & 3.68 & $12.2 \pm 0.69$ & 3.20 & 0.5 \\
\hline $\begin{array}{l}\text { Mother's dependency and lack } \\
\text { of self-sufficiency }\end{array}$ & $15.5 \pm 0.45$ & 2.20 & $14.3 \pm 0.51$ & 2.43 & 1.9 \\
\hline
\end{tabular}

Fig. 1. Calculations of primary statistics of the PARI data.

According to the data obtained, these indicators are more pronounced for women whose children have intellectual disabilities and attend an adaptive sports school (ASS). But in general, one should recognize a trend common for both groups where those indicators tend to disguise as family well-being that leads to further neurotization of all members of such a family.

We now go on to consideration of the second cell in PARI spreadsheet, which is "Parentchild relationship". Meaningful results were obtained here on indicators grouped in the cell "Excessive concentration on the child". Since the comparison of the two groups by means of the Student's t-test showed no significant differences (uncertainty zone), the indicators were ranked $(8 *(8+1) / 2=36, \mathrm{~A}=36)$ as it is presented in Figure 2. Common and priority indicator for all the participants under study was the one described as "Desire to secure and protect the child". The modality of this indicator will have a negative meaning in combination with indicators following it in the cell, which are also common for both groups: "Breaking down the child's resistance and suppressing their will" as well as "Elimination of all the outside influences in the family". 


\begin{tabular}{|c|c|c|c|c|}
\hline \multirow{2}{*}{$\begin{array}{c}\text { Names of indicators in the cell "Excessive } \\
\text { concentration on the child" }\end{array}$} & \multicolumn{2}{|c|}{$\begin{array}{c}\text { ASS } \\
\mathrm{n}=44\end{array}$} & \multicolumn{2}{c|}{$\begin{array}{c}\text { DYSS } \\
\mathrm{n}=42\end{array}$} \\
\cline { 2 - 5 } & $\mathrm{M}$ & $\mathrm{Rank}$ & $\mathrm{M}$ & Rank \\
\hline Creating security, fear of offending & 15.2 & 8 & 14.7 & 8 \\
\hline Breaking down resistance and suppressing will & 14.2 & 7 & 13.7 & 7 \\
\hline Elimination of outside influences in the family & 13.5 & 6 & 13.3 & 6 \\
\hline Suppression of aggressiveness & 13.0 & 5 & 12.0 & 3.5 \\
\hline Desire to accelerate the child's devel opment & 12.9 & 4 & 11.6 & 2 \\
\hline $\begin{array}{c}\text { Extreme intervention in the child's inner } \\
\text { world }\end{array}$ & 12.0 & 3 & 12.5 & 5 \\
\hline Suppression of sexuality & 11.8 & 2 & 11.1 & 1 \\
\hline $\begin{array}{c}\text { Excessive care, building dependency } \\
\text { relationships }\end{array}$ & 11.0 & 1 & 12.0 & 3.5 \\
\hline
\end{tabular}

Fig. 2. Results of data ranking in PARI spreadsheet cell "Excessive concentration on the child".

Thus, at this stage of the diagnostic study we revealed a common tendency for both groups that is formation of a dysfunctional family structure caused by increasingly destructive behavior of a woman in the family. One of possible outcome of this tendency development could be transformation into a system of co-dependent relationships, where any personal aspirations would be blocked off from position of control and guardianship. The most vulnerable ones in this regard appeared to be children and teenagers. And in families raising children with intellectual and other psycho-physiological disorders the risk of introduction of restrictive measures against their motor and cognitive activity increases several times.

In order to obtain more true and fair view on the problem of parental attitudes, all the subjects of the study were asked to do the tasks from the "Unfinished sentences" test by Sax Levy (SSCT). For assessment in accordance with the test key we used an interval scale characterizing the severity of the measured indicator within the range from neutral to negative on a scale where 0 shows absence or low indicator severity, from 1 to 4 - medium, positive indicator severity, from 5 to 8 - a strong, negative indicator severity. Since there was little spread of test results values, we deduced an average representation by finding the mode (Mo) to be a measure of the main tendency. The results are shown in the diagram (Fig. 3), where the presence of an indicator on a horizontal axis shows the measure of its severity. As an example, we can cite some statements of the study subjects concerning one of the points on the scale of attitude to fears and concerns:

My fears have repeatedly made me make mistakes - 2

My fears have repeatedly made me think, rethink - 1

My fears have repeatedly made me be inactive - 0 


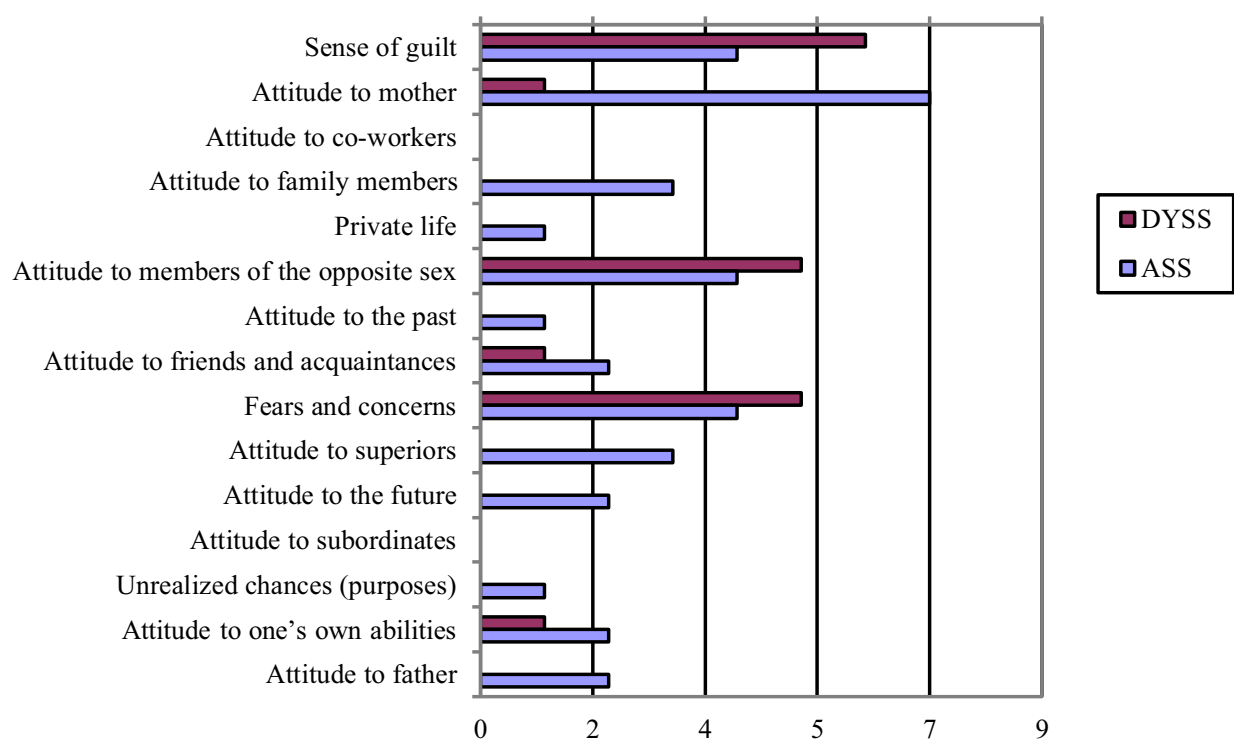

Fig. 3. Results of the calculation of the mode according to the SSCT test.

SSCT is a type of a projective technique, therefore, it enables interpretation of data in terms of the problem under study, namely, family relationships causing lack of opportunities or willingness to practice adaptive exercise therapy and sport in children with intellectual disabilities.

Based on the above, having analyzed the data presented on an interval scale from 0 to 8 , we can make conclusion concerning most meaningful indicators in the system of relations for this social section. For the group of women under study, whose children have intellectual disabilities and attend adaptive sports school (ASS), a meaningful result with negative implication was identified in the cell "Relationship with mother". This can be interpreted as relationships of family members that lack trust. In turn, for a group of women whose children attend children and youth sports school (CYSS) in the range from 4 to 8 noticeable results were in the cells "Sense of guilt", "Attitude to members of the opposite sex", "Fears and concerns". That can be illustrated by the meaning of testees's phrases, who describe their attitude to sense of guilt as emotional pain for making their relatives feel upset and anxious, desire to return to the past and change everything; disappointment in an idealized partner concerning their relationship with members of the opposite sex, presence of irrational fears and phobic disorders.

Thus, in the process of comparative analysis of specific parental attitudes, systems of relationships within the family and social relationships in two groups of women whose children attend sports schools, we came to conclusion that there are both quantitative and qualitative differences between the studied groups.

In order to consider the possibility of existence of a factor or group of factors in the sphere of family upbringing which are relevant to methodology applied for organizing physical education and sports activities for children with intellectual disabilities, we performed a factor analysis procedure based on the data from "Unfinished sentences" test by Sax Levy (SSCT). As a result, in each group under study, three factors were identified and the initial variables were noted, which gave the most meaningful figures, as presented in Figure 4. 


\begin{tabular}{|c|c|c|c|c|c|c|}
\hline \multirow{2}{*}{$\begin{array}{l}\text { SSCT Names of } \\
\text { indi cators groups }\end{array}$} & \multicolumn{3}{|c|}{$\begin{array}{c}\text { ASS } \\
\mathrm{n}=44\end{array}$} & \multicolumn{3}{|c|}{$\begin{array}{l}\text { SYSS } \\
\mathrm{n}=42\end{array}$} \\
\hline & 1 factor & 2 factor & 3 factor & 1 factor & 2 factor & 3 factor \\
\hline Attitude to father & & -0.67195 & & & & -0.75206 \\
\hline Attitude to abilities & & 0.734042 & 0.504878 & & & -0.55674 \\
\hline $\begin{array}{l}\text { Attitude to unrealized } \\
\text { goals, opportunities }\end{array}$ & -0.58814 & -0.64525 & & & 0.614298 & \\
\hline Attitude to subordinates & & -0.89959 & & & 0.502434 & \\
\hline Attitude to the future & -0.77755 & & 0.556003 & 0.783952 & & \\
\hline A ttitude to superiors & & & 0.741669 & & 0.70049 & \\
\hline $\begin{array}{l}\text { Attitude to fears and } \\
\text { concerns }\end{array}$ & 0.977261 & & & & 0.623714 & 0.503299 \\
\hline $\begin{array}{l}\text { Attitude to friends, } \\
\text { acquaintances }\end{array}$ & 0.567824 & 0.713041 & & & & 0.545784 \\
\hline Attitude to the past & & & 0.811617 & 0.690401 & & \\
\hline $\begin{array}{l}\text { Attitude to members of } \\
\text { the opposite sex }\end{array}$ & 0.543878 & -0.66458 & & 0.602474 & & \\
\hline $\begin{array}{l}\text { Attitude to one's own } \\
\text { private life }\end{array}$ & 0.970443 & & & & 0.718639 & \\
\hline $\begin{array}{c}\text { Attitude to family } \\
\text { members }\end{array}$ & & 0.609072 & 0.522005 & 0.897512 & & \\
\hline $\begin{array}{c}\text { Attitude to co-workers, } \\
\text { colleagues } \\
\text { Attitude to mother }\end{array}$ & 0.5947 & 0.66548 & & 0.863534 & & \\
\hline Attitude to sense of guilt & 0.970443 & & & & 0.704081 & \\
\hline $\begin{array}{l}\% \text { accumulated variance } \\
\text { for each factor }\end{array}$ & 39.23217 & 30.39054 & 19.68282 & 24.92549 & 20.14072 & 16.72114 \\
\hline$\%$ accumulated variance & & 89.30554 & & & 61.78735 & \\
\hline
\end{tabular}

Fig. 4. SSCT factor analysis results.

According to the SSCT, 3 factors were identified in the structure of the system of relationships within the family and social relationships for the ASS group, the total variance percentage of which was $89.305 \%$.

The 1 factor can be designated as "Negative life scenario", because of the fact that its most meaningful indicators are related to the presence of fears and concerns of making a mistake, fear of being alone, considering personal life as "everyday work" and routine, sense of guilt because of a failed marriage, lack of close confiding relationship with mother, possible transfer of bad relationship experience to friends and acquaintances, negative attitude to people of the opposite sex; and as compensation, the need for harmonious relationships with close people and devotion.

The 2 factor can be designated as "Self-doubt." The most meaningful indicators of it are related to disbelief in one's own strengths, search for support in external social environment, lack of support from family members.

The 3 factor is designated as "Lack of visible prospects" and the most meaningful indicators are associated with a predominantly negative life experience, and consequently, uncertainty about future life well-being, self-doubt and lack of self-confidence.

As a result of factor analysis of the group of women under study whose children attend classes in adaptive sports school, a certain indicator has been identified in the cell "Attitude to mother", which was common to the first and second groups of factors and indirectly to the third one. Considering the maternal aspect in terms of archetypal symbolic projection, we can highlight a number of words, such as: care, love, trust, support.

Interpretation of the results of factor analysis for the CYSS group concerning three factors looks as follows: 
The 1 factor is designated as "Positive Life Scenario"; its meaningful indicators are related to harmonious, trusting relationships between all family members; confidence in bright, happy and distinct future, where there is generational continuity and positive experience.

We decided to designate the 2 factor as "Gluing". Its meaningful indicators are related to general well-being in the interpersonal and social spheres, but at the same time there are some irrational fears and a pronounced sense of guilt. This factor can be defined as hidden and having a "cementing" effect on the structure of the family system.

The 3 factor is designated as "Seeming confidence"; its most meaningful indicators are associated with good social connections, but at the same time with doubts in one's own abilities.

As a result of a factor analysis of the group of women under study, whose children attend classes in children and youth sports school, against a background of general well-being in interpersonal and social relations, a hidden factor was revealed, which appeared to be the basic component in the structure of a dysfunctional family.

\section{Conclusions}

Thus, we conducted a diagnostic research intended to study the problem of a low percentage of children with intellectual disabilities involved in adaptive exercise therapy and sports in Russia. The hypothesis of the existence of an additional factor or group of factors in family upbringing of children attending sports activities was due to the purpose of the study that was to reveal the presence of factors which determine the methodology of organizing adaptive exercise therapy and sports activities for children with intellectual disabilities.

By means of collecting empirical data and performing statistical and factor analysis, we compared two groups of the sample and obtained quantitative and qualitative indicators.

The sample of the study comprised women who live in Russia and have children, including children with intellectual disabilities. A prerequisite for sampling was children attending physical education and sports classes in children and youth sports schools and adaptive exercise therapy and adaptive sports in adaptive sports schools respectively.

According to the results of the study, we can conclude that there are indicators in the structure of family relationships that characterize this family system as a dysfunctional one. The use of a projective technique in diagnostics made it possible to subjectify quantitative indicators and identify hidden factors for both groups. In the group of women with children without intellectual disabilities, the presence of a hidden destructive factor that threatens the integrity of the family structure was revealed. Sense of guilt underlying the relationship can eventually destroy even a very strong foundation of intergenerational family bonds and family values.

For a group of women under study, whose children have intellectual disabilities and attend adaptive sports school (ASS), manifestation of some aspects of an archetypal mother complex through such concepts as care, love, trust, support was revealed. We can say that these concepts in the context of our study are the key in the work aimed at harmonization of family and child-parent relationships. That explains the need to organize special counseling and training activities for the parents of children with intellectual disabilities aimed at correction of individual and interpersonal deviations identified during the testing. In addition, we see the need to organize joint (parent-child) practical classes on adaptive exercise therapy in the environment of the swimming pool. Formation of mental bonds of trust and closeness in the process of joint training, especially in children with disabilities, will thereby approach the solution of the problem of their active involvement in sportsoriented activities. 
Having compared the data of the sampling groups we came to the conclusion that there is a number of problems of parent-child and interpersonal family relationships in both groups, which have minor differences. In this regard, we find it appropriate to conduct further research in this area in order to find resources to solve these problems with the help of sports and recreation activities.

\section{References}

1. M. Uesugi, Latest Findings in Intellectual and Developmental Disabilities Research (2012) https://doi.org/10.5772/29953

2. Ch. Maïano, O. Hue, J. April, Journal of Intellectual Disability Research (2019) https://doi.org/10.1111/jir.12618

3. S. Alexandre, A. Honório, M. Batista, J. Santos, J. Petrica, H. Mesquita, J. Serrano, J. Ribeiro, J. Martins, IntechOpen (2019) DOI: 10.5772/intechopen.84453

4. S. Markovic-Jovanovic, J. Milovanovic, A. Jovanovic, J. Zivkovic, A. Balovic, V. Nickovic, M. Vasic, M. Ristic, Birth Defects Research 112 (2019) https://doi.org/10.1002/bdr2.1587

5. H. Memisevic, Journal of Special Education and Rehabilitation 16, 71-83 (2015) DOI: 10.1515/JSER-2015-0012

6. D. Amor, Journal of Paediatrics and Child Health 54, 1154-1158 (2018) DOI: 10.1111/jpc. 14202

7. M. Bećarević, A. Dizdarevic, Z. Ahmetović, A. Mujezinović, E. Omerkić, Acta Medica Saliniana 49 (2019) DOI: 10.5457/ams.v49i1.490

8. J. Harries, R. Guscia, T. Nettelbeck, N. Kirby, American Journal on Intellectual and Developmental Disabilities 114(4), 237-253 (2009) https://doi.org/10.1352/1944-7558114.4.237-253

9. H. Hall, The Relationships Among Adaptive Behaviors of Children with Autism Spectrum Disorder, Their Family Support Networks, Parental Stress, and Parental Coping (2008) https://doi.org/10.21007/etd.cghs.2008.0123

10. Subhash Wagh, Showkat Ganaie, International Journal of Clinical Therapeutics and Diagnosis, 56-58 (2014) DOI: 10.19070/2332-2926-1400011

11. A. Hronis, R. Roberts, L. Roberts, I. Kneebone, Journal of Intellectual Disability Research 64 (2019) DOI: 10.1111/jir.12694

12. K.Z. Altaye, S. Mondal, K. Legesse, M. Abdulkedir, BMJ Open Sport \& Exercise Medicine 5(1), e000524 (2019) https://doi.org/10.1136/bmjsem-2019-000524

13. O. Alaluf, Different Disabilities, Different Attitudes Toward Parental Involvement In School In Israeli Teachers (2018) https://doi.org/10.15405/epsbs.2018.06.70

14. L.A. Golovey, S.S. Savenysheva, E.E. Engelgardt, Social Psychology and Society 7(3), 18-32 (2016) doi:10.17759/sps.2016070302

15. Dwi Ariadni, Yayi Prabandari, DW Sumarni, Indonesian Nursing Journal Of Education And Clinic (INJEC) 2, 164 (2017) DOI: 10.24990/injec.v2i2.156 